\title{
“KONSPIRASI POLITIK” HUKUM ISLAM DI INDONESIA
}

\author{
Ubaidillah \\ Fakultas Syari'ah dan Ekonomi Islam \\ Institut Agama Islam Negeri Syekh Nurjati Cirebon \\ Email: ubaidillah_firly@yahoo.com
}

\begin{abstract}
ABSTRAK
Hukum Islam (fiqh) adalah salah satu produk hukum yang diambil dari nash-nash al-Qur'an yang bersifat dhanni (interpretable) melalui metodologi istinbathhokum (ushul fiqh) dari dalil-dalil terperinci berkaitan dengan perbuatan mukallaf yang diambil dari al-Qur'an dan al-Hadits. Perkembangan hukum tentu diiringi dan disesuaikan dengan illat hukumnya baik ada atau tidak adanya illat hokum tersebut, hal ini tentu menimbulkan "konspirasi politik" hukum Islam sebut saja misalnya dengan dikodifikasinya buku Kompilasi Hukum Islam (KHI) tidak menutup kemungkinan muatan politik praktis bersentuhan di dalamnya.Terbitnya buku Kompilasi Hukum Islam yang diramu dari berbagai kitab fiqh melalui tahapan-tahapan peraturan pemerintah sangat dibutuhkan bagi kemaslahatan masyarakatmuslim di Indonesia.Nash-nash hukum syara' yang kemudian menjadi syariat hukum Islam baik yang berkaitan dengan kemashlahatan manusia tidak terlepas dari kebutuhan pokok (dharuri), kebutuhan sekunder (hajiyyah) dan kebutuhan pelengkap (tahshiniyyah).
\end{abstract}

Kata Kunci : Konspirasi, kemaslahatan, syariat dan nash

\begin{abstract}
Islamic law (figh) is one of the legal products taken from the Qur'anic texts which are dhanni (interpretable) through the istinbathhokum (ushul fiqh) methodology of detailed arguments relating to mukallaf actions taken from the Qur' an and al-Hadith. Legal development is certainly accompanied and adapted to the illat of the law, whether or not there is a legal illat, this certainly raises the "political conspiracy" of Islamic law, for example, with the codification of the Compilation of Islamic Law (KHI) does not rule out the possibility of practical political content in it. The publication of the book Compilation of Islamic Law which is mixed from various books of fiqh through the stages of government regulation is needed for the benefit of the Muslim community in Indonesia. Syara law texts' which later became sharia law both related to human welfare are inseparable from basic needs (dharuri ), secondary needs (hajiyyah) and complementary needs (tahshiniyyah).
\end{abstract}

Keywords : Conspiracy, benefit, Shari'a and texts 


\section{A. PENDAHULUAN}

Dalam catatan sejarah di masa kolonial Belanda dan Jepang, keberadaan hukum Islam di Indonesia diselimuti faktor keterbelangan dalam berpikir, ia lebih tersuduk ke aspek ibadah, bercorak satu madzhab, memperkeras taklid, adanya larangan talfik dan larangan membuka pintu ijtihad. Kenyataan ini masih dipersuram dengan miskinnya kajian metodologis. Pemikiran hukum Islam lebih mementingkan hasil (produk hukum) daripada proses penyimpulan hukum, mengabaikan mashlahah sebagai salah satu tujuan hukum Islam, karena pendapat ulama seringkali diimpor begitu saja sebagai sebuah kebenaran tanpa dikaji ulang. ${ }^{1}$

Islam yang masuk ke Indonesia pada waktu itu lebih dipahami sebagai proses Arabisasi atau lenih berkiblat kepada Arab dengan menafikan nilai-nilai lokalitas. Lebih parah lagi, kondisi ini diperkeruh dengan lahirnya kebijakan pemerintah kolonial melalui teori resepsinya, yakni hukum adat dijadikan sebagai patokan dalam penyelenggaraan hukum di Indonesia, sedangkan Hukum Islam baru bisa dijadikan sebagai rujukan setelah terlebih dahulu diresepsi hukum adat. Kondisi inilah yang kiranya yang menggugah kesadaran para intelektual muslim untuk melakukan perubahan, agar muslim di Indonesia tidak terjebak pada perdebatan-perdebatan yang tidak menyentuh permasalahan substantif.

T.M Hasbi Ash-Shiddieqy (selanjutnya disebut Hasbi) merupakan salah satu tokoh yang ikut mendukung gerakan 'kembali kepada Al-Qur'an dan

1 Yudian Wahyudi, Ushul Fiqh versus Heurmeneutik:Membaca Islam dari Kanada dan Amerika, Cet. V (Yogyakarta; Pesantren Nawesea Press, 2007), 28.
As-Sunnah sebagai bentuk perlawanan terhadap pengekangan hukum Islam yang didominasi oleh hukum adat tersebut. Selanjutnya, Hasbi menganggap perlu untuk menggagas sebuahfiqh yang berorientasi lokal yang lenih dikenal dengan istilah "fiqh keindonesiaan". Hal ini didasarkan pada pemahaman umat Islam Indonesia terhadap hukum Islam selama ini masih sangat kearab-araban (arabisme), sehingga perlu kiranya dibangun sebuah kesadaran untuk menggagas "fiqh lokalitas" yang dapat mengakomodasi kepentingan sosial muslim lokal Indonesia. Fiqh keindonesiaan yang dimaksudkan oleh Hasbi adalah fiqh yang didasarkan pada kepribadian dan karakter bangsa Indonesia itu sendiri. Namun demikian, menurut catatan kritis Yudian Wahyudi, gagasan Hasbi tersebut masih "menggantung" dan belum dirumuskan secara detail bagaimana konstruksi metodologi pemikiran dan aplikasinya. Gagasan Hasbi baru sebatas pada dataran konsepsional semata karena ia tidak memiliki kesempatan untuk mewujudkan langsung secara konstitusional. $^{2}$

\section{B. PEMBAHASAN}

Perkembangan hukum Islam di antaranya juga terkait erat dengan masalah politik, karena persoalan yang mula-mula timbul dalam Islam memang politik yang berkisar pada masalah suksesi kepemimpinan dan masalah dosa besar murtakib al-kabair kemudian melebar ke dalam masalah theology dan hukum. ${ }^{3}$ Kelompok-kelompok itu di antaranya eksis

${ }^{2}$ Yudian Wahyudi, Mengenang jasa Prof. Dr. T.M. Hasbi ash-Shiddieqy (Yogyakarta: Forum Studi Hukum Islam Fakultas Syariah IAIN Sunan Kalijaga, 1994) 3-16.

${ }^{3}$ Harun Nasution, Islam Ditinjau dari Berbagai Aspeknya, Jilid II (Jakarta: UI Press, 1984) 
sampai saat ini dengan membawa pengaruh pada perkembangan hukum Islam seperti ahlusunnah dengan empat madzhab besarnya, syiah dengan fiqh siyasahnya, ${ }^{4}$ dan kelompok yang tinggal pengaruhnya saja dalam hukum Islam seperti aliran iktizal. ${ }^{5}$

Hukum Islam datang di bumi Indonesia (Nusantara) bersamaan dengan datangnya orang Islam di bumi Nusantara. ${ }^{6}$ Dari Komunitas Islam muncul kerajaankerajaan Islam dan berakibat munculnya badan peradilan yang berdasarkan hukum Islam yang di antaranya memperoleh bentuk ketatanegaraan dalam masa kesultanan itu. Pada masa penjajahan Belanda, pemerintah Hindia-Belanda mengakui secara formal keberadaan peradilan Agama ditegaskan bahwa agama merupakan peradilan khusus dengan kewenangan mengadili perkara perdata tertentu untuk golongan tertentu pula. Kompetensi absolut peradilan agama, yakni untuk memeriksa, memutus dan menyelesaikan perkara-perkara di tingkat pertama antara orang-orang yang beragama Islam di bidang: perkawinan, kewarisan, wasiat, hibah, wakaf dan ekonomi Islam. Hukum materiil yang diterapkan di Indonesia khususnya melalui pengadilan agama tidak selamanya sama dengan apa yang diajarkan oleh para fuqaha dalam kitab fiqh karena terkadang berpedoman pada hukum positif yang mengaturnya. ${ }^{7}$

\footnotetext{
4 Kenneth w. Morgan, Islam The Straigh Path (__ : The Ronald Press, 1958) 180-

5 Joesoef Soeyb, Peranan Aliran Iktizal dalam Perkembangan Aliran Pikiran Islam (Jakarta: Pustaka Al-Husna, 1982) 34.

${ }^{6}$ Muhammad Aud Ali, Kedudukan Hukum Islam dalam Sistem Hukum Indonesia (Jakarta: Risalah, 1984) 7.

${ }^{7}$ Abd. Shomad, Hukum Islam Penormaan Prinsip Syariah dalam Hukum Indonesia (Jakarta: Kencana Prenada Media Group, 2012) 3-4.
}

(fiqh) Indonesia, yaitu "fiqh yang ditentukan berdasarkan kepribadian dan karakter bangsa Indonesia", tentunya merupakan keasyikan tersendiri bagi mereka yang berkepentingan. Pro dan kontra merupakan bagian yang tak terpisahkan, sekaligus menjadi bumbu penyedap. Pihak-pihak yang menolak biasanya berangkat dari asumsi bahwa "fiqh (bukan syari'ah) bersifat universal". Pandangan ini diwaklili oleh Kuntowijoyo, Alie Yafie dan Ibrahim Hosen yang tegastegas menolak kehadiran Fiqh Indonesia. ${ }^{8}$

Semangat pembaruan yang terjadi di Indonesia pada awal-awal abad XX telah melahirkan dua kelompok umat Islam yang saling bersebrangan, yaitu modernis dan tradisionalis. Kaum modernis berusaha melakukan gerakan reformasi agama dalam rangka mengajak umat Islam Indonesia untuk kembali kepada sumber utama Islam, Al-Quran dan As-Sunnah dan berusaha meninggalkan tradisi taqlid kepada empat imam madzhab dengan mencoba melakukan pendekatan ilmiah dalam memahami ajaran Islam yang diyakininya guna meningkatkan kemajuan peradaban Islam. Kaum modernis juga menganjurkan adanya penafsiran ulang atas Islam secara fleksibel dan berkelanjutan sehingga kaum muslim dapat mengembangkan institusi pendidikan, hukum dan politik sesuai dengan kondisi modern. Sementara kaum tradisionalis, berusaha mempertahankan tradisi bermadzhab (taqlid) kepada empat imam madzhab, bersamaan dengan tertutupnya pintu ijtihad bagi umat Islam yang didasari oleh asumsi hilangnya sejumlah kemampuan otoritatif untuk

8 Yudian Wahyudi, Ushul Fiqh versus Heurmeneutik, V (Yogyakarta :Pesantren Nawesea Press, 2007) 35-36. 
menjalankan ijtihad tersebut. Karena itu, pendapat imam madzhab merupakan referensi utama untuk menyelesaikan berbagai permasalahan agama. $^{9}$

Para ahli hukum Barat menilai hukum Islam sebagai hukum yang menolak positivisme, kecuali J.N.D Anderson. Coulson sebagai penganut dan pendukung positivisme, tertarik kepada kepentingenkepentingan masyarakat dan menilai hukum Tuhan dari sudut positivistik. Hukum Islam menurutnya agamis karenanya bukan hukum dalam pengertian modern. Berbeda dengan Coulson, Anderson menyatakan bahwa hukum Islam tidak hanya sekedar hukum agamis yang secara esensial tidak dapat diubah. Hukum Islam juga menjangkau setiap segi kehidupan dan setiap bidang hukum. Oleh karena itu, dalam teori, hukum Islam tidak dapat tidak dapat ditanding oleh hukum manapun. ${ }^{10}$

Di kalangan pemikir muslim, Imam Al-Ghazali menyatakan bahwa hukum Islam adalah hukum yang memasrahkan diri kepada Tuhan. Al-Qur'an adalah kitab pertama yang menjelaskan adanya hukum dengan istilah sunnatullah. Sunnatullah di alam semesta disebut hukum alam, di dalam diri manusia disebut hukum moral."Setiap makhluk memiliki hukum alam sendiri", demikian menurut J. Maritain. ${ }^{11}$ Ringkasnya, hukum alam adalah sesuatu yang ideal dan ontologis Ideal karena didasarkan pada hakikat manusia dan pada strukturnya yang tidak berubah-ubah dan keperluan-keperluan yang tidak dapat dipahami yang ada hubungan dengannya.

9 Asy-Syir'ah, Jurnal ilmu Syari'ah dan Hukum, (Yogyakarta: Fakultas Syari'ah dan Hukum UIN Sunan Kalijaga, 2012) 32-33

10 J.N.D. Anderson, Islamic Law. 16

11 J. Maritain, Dua Unsur Hukum Alam (Jakarta: Abardin, 1987) 85.
Ontologis karena hakikat manusia adalah sesuatu kenyataan wujudnya, yang di samping ada tidak terdapat secara terpisah, tetapu ada dalam tiap makhluk manusia sehingga hukum alam bersemayam sebagai suatu susunan yang ideal dalam keadaan dari setiap manusia yang ada. ${ }^{12}$

Hukum Islam secara garis besar mengenal dua macam sumber hukum, pertama sumber hukum yang bersifat naqliy dan sumber hukum yang bersifat aqliy.Sumber hukum naqliy ialah AlQur'an dan Al-hadits, sedangkansumber hukum aqliyialah hasil usaha menemukan hukum dengan mengutamakan olah pikir dengan beragam metodenya. ${ }^{13}$ Kandungan hukum dalam Al-Qur'an dan Al-hadits kadang kala bersifat prinsipiil yang general (dhanni) sehingga perlu interpretasi untuk penerapannya. Al-Qur'an dan Al-hadits sebagai sumber ilmu syariah dengan bantuan ulum al-qur'an dan ulum al-hadits, meliputi tiga hukum yaitu: pertama, hukum yang menyangkut keyakinan orang dewasa (mukallaf), kedua, hukum etika (akhlak) yang mengatur bagaimana seseorang berbuat kebaikan dan meninggalkan kejelekan. Ketiga, hukum-hukum praktis (amaliyah)yang mengatur perbuatan, ucapan, perikatan dan berbagai tindakan hukum seseorang. Hukum yang mengatur hubungan antar manusia sebagai individu dengan individu lainnnya dalam hubungannya dalam perikatan, pertukaran, kepemilikan harta dan hubungan lain melahirkan hukum perdata (al-ahkam al-

12 Ahmad Hasan Ridwan, Irfan Safrudin,Dasar-Dasar Epistemologi Islam, (Bandung: CV.Pustaka Setia, 2011) 169

${ }^{13}$ Abdul Wahab Khallaf, Mashadiru alTasyri' al-Islami Fima la Nashsha Fihi ( Kuwait; Darul Qolam, 1972) 
madaniyyah), dalam aspek ini lahirlah Hukum Ekonomi Islam. ${ }^{14}$

Sumber hukum aqliy yang mengutamakan olah pikir ini terkait erat dengan istilah figh dan penerapan hukum Islam di berbagai kawasan dunia, tak terkecuali di Indonesia. ${ }^{15}$ Sumber hukum inilah yang juga berperan banyak dalam perbedaan pendapat di kalangan ahli hukum Islam menyangkut berbagai aspek kehidupan yang kemudian menimbulkan madzhab-madzhab hukum Islam.Walaupun pada hakikatnya perbedaan pendapat para madzahib itu disebabkan perbedaan ijtihad ushul al-fiqh terkait perbedaan teknis pemahaman, kepentingan pribadi atau kelompok tertentu dalam aspek politik, serta perbedaan kualitas serta kapasitas intelektual pada masing-masing pendiri dan pengikutnya. ${ }^{16}$ Perbedaan madzhabmadzhab hukum Islam, tidaklah madzhabmadzhab itu keluar dari syariat Islam selama madzhab-madzhab itu merujuk AlQur'an dan Al-hadits dalam ushul fiqhnya. ${ }^{17}$ Perbedaan pendapat dalam merumuskan hukum Islam disebabkan beberapa alasan yang dapat disimpulkan pada satu alasan utama yang dapat menampung alasan lainnya, yaitu perbedaan dalam memahami dalil syara, AlQur'an dan Al-hadits. ${ }^{18}$ Di samping itu, di antara ulama telah ada yang punya pendapat

14 Abd. Shomad, Hukum Islam Penormaan Prinsip Syariah dalam Hukum Indonesia (Jakarta: Kencana Prenada Media Group, 2012) 32-33

15 Abd. Somad, Hak Istri Untuk Mencerai Suami, Imarta, vol. 3 no. 4 Oktober-Desember 2001. 250-251.

16 Muchtar Adam, Perbandingan Madzhab dalam Islam Permasalahnnya (Bandung: Rosdakarya, 1991)209.

17 Tjun Surjaman, Hukum Islam di Indonesia, Penularan dan Praktek (Bandung: Remaja Rosdakarya, 1991) V.

18 Muhammad Khudhari Bek, Tarikh Tasyri' Islam (Cairo: Mathbaah Istiqomah, 1934) 134-141. sebelum menelaah dalil dan pencarian serta penelaahan dalil kemudian hanya dalam rangka usaha menguatkan pendapatnya.Situasinya menjadi terbalik, syariah yang pada dasarnya menjadi sumber dan penuntun dalam merumuskan hukum, menjadi berfungsi sebagai penguat pendapat yang muncul. Kondisi semacam ini muncul karena pengaruh politik yang dianutnya atau karena adat istiadat yang mereka anggap dapat disesuaikan dengan hukum Islam. Hukum Islam di antaranya memuat beberapa ketentuan yang merombak beberapa ketentuan tradisi pra Islam pada masyarakat Arab Jahiliah asathir al-awwalin mitologi pra Islam pada masyarakat arab kuno dan tradisi sekitarnya. ${ }^{19}$

Hukum Islam yang sebenarnya tidak lain dari pada fiqh Islam atau syari'at Islam, yaitu koleksi daya upaya para fuqaha dalam menerapkan syari'at Islam sesuai dengan kebutuhan masyarakat. Istilah hukum Islam walaupun berlafadz arab namun telah baku menjadi bahasa Indonesia, sebagai terjemahan dari fiqh Islam atau syari'at Islam yang bersumber dari Al-Qur'an, alHadits, ijma' dan qiyas.Al-Qur'an dan alHadits melengkapi sebagian besar dari hukum-hukum Islam dalam bidang fiqh.Kemudian para sahabat dan tabi'in menambahkan atas hukum-hukum itu, aneka hukum yang diperlukan untuk menyelesaikan permasalahan-permasalahan yang timbu dalam masyarakat. Karenanya dapatlah kita katakan bahwa syari'at (hukum) Islam, adalah hukum-hukum yang bersifat umum dan kulli yang dapat diterapkan dalam perkembangan hukum Islam menurut kondisi dan situasi

19 Abd. Shomad, Hukum Islam Penormaan Prinsip Syariah dalam Hukum Indonesia (Jakarta: Kencana Prenada Media Group, 2012) 36-38. 
masyarakat.Di Indonesia buku Kompilasi Hukum Islam (KHI) adalah sebuah buku produk hukum Islam yang dirami dari berbagai kitab fiqh yang tentu disesuaikan dengan perkembangan masyarakat di Indonsia. $^{20}$

Hukum Islam (fiqh) adalah hukum yang terus hidup, sesuai dengan kebutuhan masyarakat baik di bidang ibadah, ekonomi, perkawinan, hukum pidana maupun politik senantiasa mempunyai gerak yang tetap dan perkembangan yang terus menerus.Karenanya hukum Islam senantiasa berkembang, dan perkembangan itu merupakan tabi'at hukum Islam yang terus hidup, karenanyapun hukum Islam terdiri atas empat dasar, yaitu Al-Qur'an, al-Hadits, Ijma dan qiyas. Menurut Ibnu Khaldun, ijma' dan qiyas tumbuh di masa sahabat. Mempergunakan ra'yu atau qiyas tergambar pada permulaannya dalam jawaban Mu'adz kepada Rasulullah ketika Mu'adz diangkat menjadi hakim di Yaman. Dengan terjadinya ijma' dan ra'yu atau qiyas jadilah sendi hukum Islam empat perkara. Dua yang pertama tumbuh di masa Rasulullah yaitu Al-Qur'an dan al-Hadits dan dua kedua tumbuh di masa sahabat yaitu ijma' dan qiyas atau ra'yu. Maka pada masa sahabat, mulailah hokum Islam menempuh perkembangan berdasarkan kepada kebutuhan masyarakat dalam kehidupannya, Sepanjang sejarah hokum Islam bahwa bidang muamalah mempunyai perkembangan dalam persoalan hukumhukum Islam yang berkaitan dengan transaksi ekonomi.

Hukum Islam mempunyai kajian yang sangat luas yang melengkapi kegiatan

${ }^{20}$ Muhammad Muslehudin, Filsafat Hukum Islam dan Pemikiran Orientalis (Yogyakarta: Tiara Wacana, 1991) 45-47 masyarakat yang beraneka ragam. Maka di antara hukum Islam, ada hokum-hukum ibadat, ada hukum-hukum perikatan (uqud), hukum-hukum yang diterapkan pada keadaan-keadaan yang dikecualikan (luar biasa), hukum-hukum yang berdasarkan maslahat mursalah, hukum-hukum jihad perang dan tawanan dan hukum-hukum yang berlaku dalam menyerang musuh dan mempertahankan Negara (bidang siyasah/politik.Tujuan syar'i dalam pembentukan hukumnya, yaitu merealisir kemaslahatan manusia dengan menjamin kebutuhan pokoknya (dharuriyah) dan memenuhi kenutuhan sekunder (hajiyyah) serta kebutuhan pelengkap mereka (tahshiniyyah) mereka, jadi tidak ada tujuan dari hukum syara kecuali salah satu di antara unsur tersebut, di mana dari tiga unsur tersebut dapat terbukti kemaslahatan manusia.Tahsiniyah tidak berarti dipelihara jika dalam pemeliharaannya itu terdapat kerusakan bagi hajiyyah, dan hajiyyah juga tahsiniyyah tidak berarti dipelihara jika dalam pemeliharaan salah satunya terdapat kerusakan bagi dharuriyah. $^{21}$

Kaidah pertama ini menjelaskan tujuan umum syari' dalam pembentukan hokum syara.Baik hukum itu bersifat taklifi (pembebanan yang wajib) atau wadhi'i (positif, buatan manusia) dan menjelaskan juga tingkatan-tingkatan hUkum menurut tujuannya.Mengetahui tujuan hukum syari', dalam pembentukan hukumnya adalah termasuk sesuatu yang amat penting untuk dijadikan alat penolong untuk mengetahui dengan jelas nash-nash pembentukan hokum itu, dan untuk menerapkan nashnash itu terhadap berbagai terhadap berbagai peristiwa. Di samping itu juga

21 Abdul Wahab Khallaf, Kaidah-Kaidah Hukum Islam (Ilmu Ushul Fiqh) (Jakarta: PT. Raja Grafindo Persada, 329-330. 
untuk mengistinbath hokum yang tidak ada nashnya, karena isyarat lafal dan ungkapan pada makna itu terkadang mengandung beberapa segi, maka yang dapat menguatkan salah-satu di antara beberapa segi ini ialah memperhatikan tujuan syar'i, dan karena sebagian nash itu terkadang lahirnya saling kontradiksi, maka yang dapat menghilangkan kontradiksi ini dan dapat mengkompromikan nash-nash itu atau menguatkan salah satunya adalah memperhatikan tujuan syari'. Dan karena kebanyakan peristiwa yang timbul itu terkadang tidak terjangkau oleh ungkapan nash. Sedangkan mengetahui hukum peristiwa itu dengan dalil syara apa saja, sangat diperlukan. Maka yang dapat memberi petunjuk dasar menentukan dalil ini (umpamanya) adalah mengetahui tujuan syara'.

Oleh karena itu, para penguasa hukum di pemerintahan sekarang, meletakkan catatan-catatan yang berupa penafsiran yang dapat menjelaskan tujuan pembuatan undang-undang secara umum dan dapat menjelaskan tujuan khusus dari setiap pasalnya.Catatan-catatan yang bersifat penafsiran dan pembahasan serta penelitian yang terjadi di tengah-tengah menghadirkan undang-undang dan melaksanakannya adalah bantuan penguasa hukum untuk memahami undang-undang dan menerapkannya bersama teks, jiwa dan pengertiannya.Begitu juga, nash-nash hukum syara' itu tidak dapat dimengerti menurut jalannya yang benar kecuali apabila telah diketahui tujuan syari' dalam mensyariatkan hukum-hukum itu. Juga telah diketahui bagian-bagian peristiwa yang kemudian diturunkanlah hukumhukum yang ada di dalam al-Qur'an dan alHadits.
Tujuan umum syari' dalam pembentukan hukum itulah yang akan dijelaskan dalam kaidah ushuliyyah yang pertama ini, sedangkan bagian peristiwa yang akan menjadi latar belakang pembentukan hukum itu, dijelaskan dalam kitab-kitab tafsir dan asbabun nuzul (sebabsebab turun ayat al-Qur'an\} serta haditshadits yang sahih.

Bunyi kaidah ushuliyyah itu bahwa tujuan umum syari' dalam mensyari'atkan hokum ialah merealisir kemashlahatan manusia dalam kehidupan ini, memberikan kebaikan bagi mereka dan menghilangkan keburukan dari mereka. Karena kemashlahatan manusia dalam kehidupan ini terdiri dari beberapa hal yang bersifat dharuriyah (kebutuhan pokok) hajiyyah (kebutuhan sekunder) dan tahsiniyyah (kebutuhan pelengkap). ${ }^{22}$

\section{DAFTAR PUSTAKA}

Adam, Muchtar. Perbandingan Madzhab dalam Islam Permasalahnnya Bandung: Rosdakarya, 1991.

Ali, Muhammad Aud. Kedudukan Hukum Islam dalam Sistem Hukum Indonesia, Jakarta: Risalah, 1984.

Anderson, J.N.D, Islamic Law

Bek, Muhammad Khudhari. Tarikh Tasyri' Islam, Cairo: Mathbaah Istiqomah, 1934 134-141

'Asy-Syir'ah. Jurnal ilmu Syari'ah dan Hukum, Yogyakarta: Fakultas Syari'ah dan Hukum UIN Sunan Kalijaga, 2012.

Hasan Ridwan, Ahmad. Irfan Safrudin. Dasar-Dasar Epistemologi Islam, Bandung: CV. Pustaka Setia, 2011.

J. Maritain. Dua Unsur Hukum Alam, Jakarta: Abardin, 1987.

22 Abdul Wahab Khallaf, Kaidah-Kaidah Hukum Islam (Ilmu Ushul Fiqh) (Jakarta: PT. Raja Grafindo Persada, 1994) 329-331 
Muhammad Khudhari Bek, Tarikh Tasyri' Islam (Cairo: Mathbaah Istiqomah, 1934) 134-141

Morgan, Kenneth w. Islam The Straigh Path, London: The Ronald Press, 1958.

Muslehudin, Muhammad. Filsafat Hukum Islam dan Pemikiran Orientalis Yogyakarta: Tiara Wacana, 1991

Nasution, Harun, Islam Ditinjau dari Berbagai Aspeknya, Jilid II, Jakarta: UI Press, 1984

Shomad, Abd. Hukum Islam Penormaan Prinsip Syariah dalam Hukum Indonesia, Jakarta: Kencana Prenada Media Group, 2012.

Shomad, Abd. Hak Istri Untuk Mencerai Suami, Imarta, vol. 3 no. 4 Oktober-Desember 2001. 250-251.

Soeyb, Joesoef. Peranan Aliran Iktizal dalam Perkembangan Aliran Pikiran Islam, Jakarta: Pustaka Al-Husna, 1982.

Surjaman, Tjun. Hukum Islam di Indonesia, Penularan dan Praktek (Bandung: Remaja Rosdakarya, 1991) V.

Wahyudi, Yudian. Ushul Fiqh versus Heurmeneutik:Membaca Islam dari Kanada dan Amerika, Cet. V Yogyakarta; Pesantren Nawesea Press, 2007.

jasa Prof Dr. TM. Hasbi ash-Shiddieqy Yogyakarta: Forum Studi Hukum Islam Fakultas Syariah IAIN Sunan Kalijaga, 1994.

Wahab Khallaf, Abdul. KaidahKaidah Hukum Islam (Ilmu Ushul Fiqh) (Jakarta: PT. Raja Grafindo Persada, 1994.

Mashadiru al-Tasyri' al-Islami Fima Nashsha Fihi, Kuwait; Darul Qolam, 1972. 